\title{
PERAN MODEL SOCIAL LEARNING DALAM MENINGKATKAN KOMPETENSI PETANI GARAM DI KABUPATEN PAMEKASAN
}

\author{
Umi Hanik, Mutmainah
}

\author{
Prodi Pendidikan Guru Sekolah Dasar, Jurusan Ilmu Pendidikan, \\ Fakultas Ilmu Pendidikan, Universitas Trunojoyo Madura \\ umy_tenmat@yahoo.com
}

\begin{abstract}
This study aims to determine the role of social learning models in improving the competency of salt farmers in Pamekasan Regency. The research approach used is qualitative research with grounded theory. Data collection techniques using depth interviews, observation and documentation studies. The results of the study showed that increasing the competency of salt farmers through social learning models was carried out by presenting examples of behavior from aspects: 1) knowledge (knowledge); 2) skills (skills); 3) self concept; 4) personal characteristics (traits); and 5) motives (motives). The role of the social learning model for increasing salt farmers in Pamekasan Regency is: 1) to increase knowledge so that farmers have several alternative ways to make salt to produce quality; 2) developing the competency of salt farmers through the delivery of information; 3) foster an attitude of helping others; and 4) fostering a cooperative attitude towards outside parties who wish to establish cooperation.
\end{abstract}

Keywords: social learning model, programmed imitation, and independent imitation

\begin{abstract}
Abstrak
Penelitian ini bertujuan mengetahui peran model social learning dalam meningkatkan kompetensi petani garam di Kabupaten Pamekasan. Pendekatan penelitian yang digunakan adalah penelitian kualitatif dengan grounded theory. Teknik pengambilan data menggunakan depth interview, observasi dan studi dokumentasi. Hasil penelitian menunjukkan bahwa peningkatan kompetensi petani garam melalui model social learning dilakukan dengan
\end{abstract}


menyajikan contoh perilaku dari aspek: 1) pengetahuan (knowledge); 2) keterampilan (skill); 3) konsep diri (self concept); 4) karakteristik pribadi/sifat (traits); dan 5) motif (motives). Peran model social learning untuk peningkatan petani garam di Kabupaten Pamekasan adalah: 1) menambah pengetahuan sehingga petani memiliki beberapa alternatif cara membuat garam hingga produksinya berkualitas; 2) mengembangkan kompetensi petani garam melalui penyampaian informasi; 3) menumbuhkan sikap menolong orang lain; dan 4) menumbuhkan sikap kooperatif terhadap pihak-pihak luar yang berkeinginan menjalin kerjasama.

Kata Kunci: model social learning, imitasi terprogram, dan imitasi mandiri

\section{PENDAHULUAN}

Perpaduan antara tradisi dan kondisi alam telah menjadikan Madura sebagai produsen garam rakyat terbesar di Indonesia. Kabupaten Pamekasan yang terletak di pulau Madura merupakan salah satu kabupaten penghasil garam dengan luas lahan (lahan garam rakyat dan non-rakyat) 2.070,5 Ha. Sebagai daerah penghasil garam mulai sekitar pertengahan abad XIX (setelah tahun 1870) (Ricklefs, 2007: 286), para petani garam khususnya petani garam di kabupaten Pamekasan saat ini tentu memiliki kompetensi tentang cara memproduksi garam dari para leluhur. Kompetensi tersebut dapat meningkat melalui kegiatan sosialisasi, pelatihan dan lainnya yang dilakukan oleh dinas terkait dalam hal ini adalah Dinas Perikanan Kabupaten Pamekasan. Namun ternyata dukungan pemerintah melalui program yang dijalankan pencanangan Swasembada Garam Nasional pada akhir tahun 2010 dan mulai tahun 2011 pelaksanaan program nasional Pemberdayaan Usaha Garam Rakyat (PUGAR), belum semuanya dapat diterima atau bahkan dijalankan oleh sebagian petani. Hal ini menjadi permasalahan bagi pemerintah dalam upayanya meningkatkan kompetensi petani garam.

Hambatan yang cukup berat bagi pemerintah ketika menghadapi pola pikir petani garam yang merupakan bagian dari masyarakat Madura -bahwasannya sangat menjunjung tinggi kehormatan dan harga diri (Wahyudi, 2015: 3 dan 7). Kehormatan dan harga diri menjadi pembatas masuknya informasi baru - misalnya tentang bagaimana tata cara memproduksi garam sehingga menghasilkan garam berkualitas dalam jumlah yang banyak. Pengetahuan yang diperoleh secara turun temurun dari leluhur dianggap sudah cukup untuk memproduksi garam. Sebelum tahun 2010, pengelolaan garam di kabupaten Pamekasan masih menggunakan cara tradisional dan belum menggunakan teknologi.

Berdasarkan hasil kajian terdahulu yang telah dilakukan oleh peneliti, saat ini, diperlukan sebuah kajian yang komprehensif terkait pendekatan-pendekatan yang dapat diimplementasikan pada petani garam di Kabupaten Pamekasan untuk mengubah pola pikir sehingga kompetensinya dapat meningkat. 
Model social learning sebagai suatu pendekatan dengan menggunakan teori observational learning dianggap besar pengaruhnya dalam mengatasi permasalahan petani garam. Teori observational learning adalah sebuah teori yang mengungkapkan bahwasannya belajar dapat dilakukan melalui sebuah pengamatan. Sebagian besar upaya belajar manusia terjadi melalui penyajian contoh perilaku (modeling) kemudian melakukan peniruan (imitation) (Bandura, 1986: 17-18). Hal ini dapat diartikan bahwa petani garam dapat mengubah pola pikir dan perilakunya sendiri dengan melihat cara orang atau kelompok orang mereaksi atau merespon sebuah stimulus tertentu. Petani garam juga dapat mempelajari respon-respon baru melalui pengamatan terhadap perilaku contoh terhadap proses teori dari orang lain, misalnya masyarakat lain atau fasilitator (Syah, 2013: 79-80). Dari pernyataan tersebut dapat disimpulkan bahwasannya penyajian contoh perilaku (modeling) dapat diprogram misalnya melalui sosialisasi, pendidikan atau pelatihan dan lainnya. Jadi masyarakat lain atau fasilitator memiliki peran yang sangat penting.

Terkait kompetensi, dengan merujuk pada penjelasan Spencer and Spencer (1993: 9-11) bahwasannya kompetensi dikategorikan kedalam lima aspek, yaitu: 1) pengetahuan (knowledge) yaitu informasi yang dimiliki seseorang untuk bidang tertentu, 2) ketrampilan(skill) yaitu kemampuan untuk melaksanakan suatu tugas tertentu baik secara fisik maupun mental, 3) konsep diri (self concept) yaitu sikap dan nilai-nilai yang dimiliki seseorang, 4) motif (motives) merupakan kekuatan pendorong untuk mencapai tujuan, 5) pribadi/sifat (traits) yaitu watak yang membuat orang untuk berperilaku atau bagaimana seseorang merespon sesuatu dengan cara tertentu-seperti percaya diri, kontrol diri, ketabahan dan daya tahan.

Model social learning yang dipaparkan oleh Albert Bandura dan Muhibbin Syah diatas memungkinkan adanya peningkatan kompetensi petani garam. Peningkatan kompetensi tersebut akan maksimal jika penyajian contoh perilaku (modeling) bukan hanya dari aspek pengetahuan dan keterampilan saja tetapi juga dari aspek konsep diri, motif dan pribadi/sifat.

Tujuan umum penelitian ini adalah untuk mengetahui implementasi model social learning dalam meningkatkan kompetensi petani garam di Kabupaten Pamekasan. Secara khusus, tujuan penelitian ini untuk mendeskripsikan peran model social learning dalam meningkatkan kompetensi petani garam di Kabupaten Pamekasan Madura.

\section{METODE PENELITIAN}

Sesuai tujuan penelitian, pendekatan yang digunakan dalam penelitian ini adalah secara kualitatif dengan gounded theory methodology (Yusuf, 2017: 342). Pada kajian ini difokuskan model social learning yang telah diimplementasikan di kabupaten Pamekasan. Secara spesifik, difokuskan pada kajian peran model social learning dalam meningkatkan kompetensi petani garam guna memperoleh rekomendasi yang bermanfaat.

Sumber data menggunakan data primer dan data sekunder. Teknik pengambilan data primer dilakukan melalui wawancara mendalam (in-depth interview) dan observasi, sedangkan data 
sekunder melalui studi dokumentasi (Denzin dan Lincoln, 1994: 9).

Teknik penentuan informan pada penelitian ini menggunakan purposive sampling dan snowball sampling (Yusuf, 2017: 369). Informan dalam penelitian ini adalah petani garam, klebun, kepala dinas perikanan kabupaten Pamekasan, dan pendamping/penyuluh dari dinas perikanan kabupaten Pamekasan.

Data yang diperoleh, diolah dan dianalisis menggunakan analisis kualitatif (Neuman, 2000:420), yang dilakukan pada dua tahap, yaitu 1) analisis data selama penelitian berlangsung dan 2) analisis data pasca penelitian (Huberman and Miles, 1994: 429). Langkah analisisnya: 1) reduksi data (data reduction), 2) display data (data display), dan 3) kesimpulan (conclusion) atau verifikasi terhadap data dan informasi yang diperoleh (Huberman and Miles, 1994: 428-429).

Keabsahan data menggunakan uji: 1) kredibilitas, 2) keteralihan, 3) kebergantungan, dan 4) kepastian. Uji kredibilitas menggunakan trianggulasi:
1) sumber, dan 2) metode. Uji keteralihan menggunakan uraian rinci, uji kebergantungan menggunakan teknik pemeriksaan kebergantungan dan uji kepastian data menggunakan audit kepastian (Moleong, 2000: 173-175; Yusuf, 2017: 394-398).

\section{HASIL PENELITIAN DAN PEMBAHASAN}

Sumber daya manusia (SDM) petani garam yang berkualitas merupakan salah satu faktor penting selain faktor alam dalam menghasilkan garam. SDM yang berkualitas ini dapat dilihat dari kompetensi yang dimiliki. Semakin baik kompetensi maka semakin baik pula SDMnya. Hasil kajian berdasarkan data-data lapangan yang dihimpun melalui penelitian dan kajian teori yang relevan, dapat dikemukakan kerangka konseptual peningkatan kompetensi petani garam melalui peran model social learning sebagaimana yang terlihat pada Gambar 1 berikut:

Gambar 1 Model Social Learning untuk Peningkatan Kompetensi Petani Garam

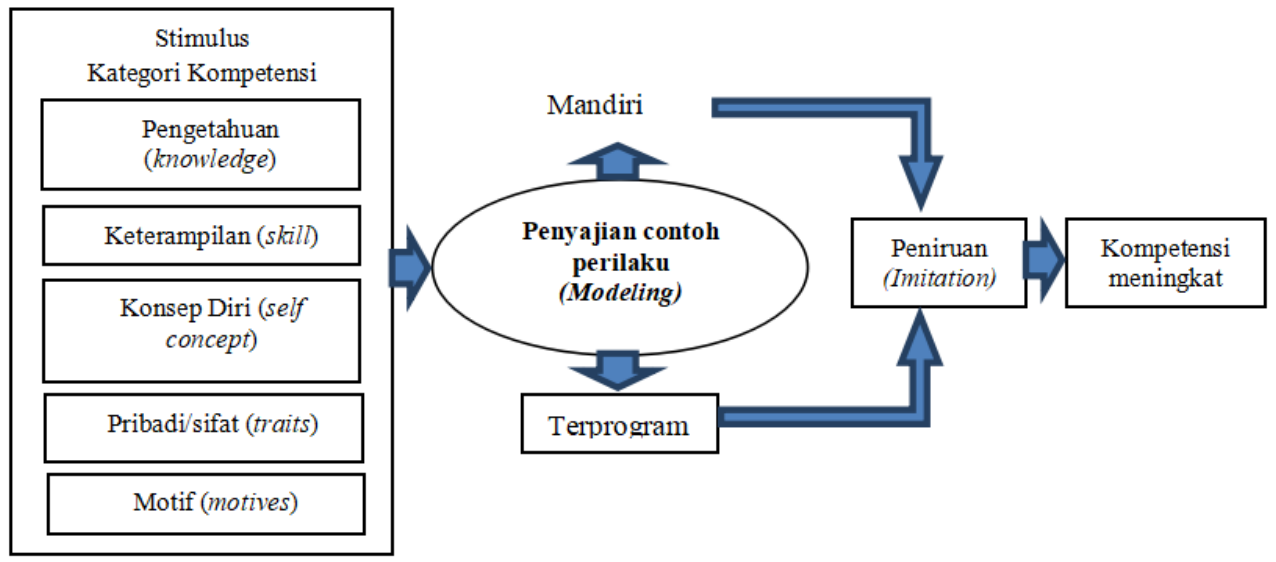


Stimulus atas penyajian contoh perilaku (modeling) yang dilakukan secara mandiri maupun terprogram dapat berupa sesuatu yang baru ataupun lama. Lama disini diartikan bahwa stimulus sudah pernah dipelajari atau dikenal sebelumnya. Perbedaan mendasar ada pada kesadaran model ketika memberikan stimulus. Jika model tidak memiliki kesadaran bahwa telah memberikan stimulus maka termasuk dalam penyajian contoh perilaku (modeling) mandiri. Sebaliknya jika model memiliki kesadaran dalam memberikan stimulus maka termasuk dalam penyajian contoh perilaku (modeling) terprogram dimana dilakukan secara terencana oleh seseorang, masyarakat atau fasilitator.

Penyajian contoh perilaku (modeling) secara terprogram ini bisa dilakukan melalui diskusi, sosialisasi, pendidikan, pelatihan atau lainnya. Modeling secara mandiri maupun terprogram jika ditindak lanjuti melalui sebuah peniruan (imitation) dapat meningkatkan kompetensi. Ada lima aspek kategori kompetensi yang dapat dilakukan melalui modeling menurut Spencer and Spencer (1993: 9-11) yaitu, 1) pengetahuan (knowledge), 2) keterampilan (skill), 3) konsep diri (self concept), 4) pribadi/sifat (traits), dan 5) motif (motives).

Paparan dan pembahasan hasil penelitian pada aspek pengetahuan dan keterampilan dilakukan secara terintegrasi. Pertimbangannya adalah keterampilan mengacu pada kemampuan dalam menggunakan dan menerapkan pengetahuan yang dimiliki. Sedangkan aspek konsep diri, pribadi/sifat dan motif dipaparkan secara terpisah.

\section{Pengetahuan (knowledge) dan keterampilan (skill)}

Pengetahuan terkait cara pembuatan garam diperoleh sebagian petani garam dari orang tua yang juga bermata pencaharian petani garam. Menurut pengakuan informan (AS, SB, HM, SG, dan MS), pada awalnya tidak memiliki keinginan untuk mempelajari cara membuat garam, namun karena tempat tinggal tidak jauh dari lokasi lahan tambak garam - sedikit demi sedikit memiliki pengetahuan dasar tentang cara membuat garam. Selanjutnya dengan alasan meneruskan usaha keluarga (AS, SB, HG, dan HM) dan tidak bisa melanjutkan sekolah karena kondisi ekonomi dan pekerjaan yang ada saat itu adalah menjadi petani garam (MS), pengetahuan cara membuat garam mulai diperdalam mulai dari mengamati, bertanya hingga berdiskusi dengan orang tua atau masyarakat lain yang dianggap mengetahui lebih banyak tentang cara membuat garam hingga keterampilan membuat garam menjadi semakin baik.

Kondisi tersebut juga dilakukan oleh informan (MS dan SG), yang memberikan pengetahuan terkait cara membuat garam kepada anaknya yang menginginkan menjadi petani garam. Pengalaman tersebut mencerminkan bahwa penyajian contoh perilaku (modeling) yang diperoleh dari orang tua atau leluhur dapat dilakukan secara mandiri ataupun terprogram.

Sedangkan beberapa program yang telah dilakukan oleh pemerintah melalui Dinas Perikanan Kabupaten Pamekasan diantaranya sebagai berikut, pertama cara membuat garam menggunakan geo isolator/geo membran pada meja 
kristalisasi. Cara ini merupakan pengembangan dari pembuatan garam secara tradisional. Kedua penerapan teknologi ulir filter. Teknik ini merupakan teknologi baru dalam pengolahan air dalam proses evaporasi, dengan melakukan penyempitan petakan-petakan pembenihan hingga membentuk ulir pada inlet dan outlet disertakan saringan (filter) yang tersusun dari ijuk, batu, pasir, ziolit dan arang. Ketiga teknologi Portugis yaitu teknologi dengan menjadikan meja kristal sebagai plat menjadi dasar meja.

Keempat adalah teknologi rumah kaca - dimana garam yang dihasilkan menggunakan teknologi rumah kaca. Kelima adalah penerapan integrasi lahan - dengan menyatukan/mengabungkan lahan tambak garam dalam satu hamparan. Pengelolaan air mulai bahan baku sampai air tua dilakukan dalam satu managemen. Program tersebut dijalankan melalui kegiatan sosialisasi, pelatihan dan pendampingan secara terprogram. Dari aspek teknis, kegiatan tersebut hanya melibatkan ketua kelompok petani garam. Selanjutnya ketua kelompok menyampaikan informasi kepada anggota kelompok petani garam lain.

Kegiatan yang dilakukan oleh Dinas Perikanan Kabupaten Pamekasan secara terprogram membawa dampak yang besar untuk peningkatan kompetensi petani garam. Petani garam memiliki pengetahuan sehingga memiliki beberapa alternatif cara untuk terampil dalam membuat garam hingga produksinya melimpah dan berkualitas sehingga dicari oleh konsumen. Namun, ada sisi negatif dari aspek teknis ketika peserta program hanya sebagian yaitu ketua kelompok (perwakilan kelompok) adalah hilangnya sebagian informasi sehingga muncul isu yang berdampak pada kekawatiran petani untuk melaksanakan program yang disarankan oleh pemerintah sehingga petani cenderung tetap memilih menggunakan cara tradisional untuk membuat garam.

Salah satu isu yang berkembang adalah tentang rasa pahit yang ditimbulkan akibat dari membuat garam menggunakan teknologi geo isolator/ geo membran (pengakuan informan SG dan AS). Konfirmasi dari pihak terkait bahwasannya rasa pahit tersebut tidak ditimbulkan akibat penggunaan geo isolator/geo membran namun lebih pada kekurangtepatan dalam mengikuti prosedur pembuatan garam. Hal tersebut menimbulkan tingginya kadar magnesium dalam garam sehingga muncul rasa pahit.

\section{Konsep diri (self concept)}

Konsep diri (self concept) erat kaitannya dengan sikap seseorang atas perilaku kerjanya yang bisa ditunjukkan melalui sikap untuk mengembangkan orang lain, membuat orang lain selaras dengan keinginannya, kemauan bekerja secara kooperatif dengan pihak lain atau bahkan kemauan untuk menjadi pemimpin kelompok, dan keinginan untuk menolong orang lain (Spencer \& Spencer, 1993: 9).

Seperti yang telah diungkapkan di bagian sebelumnya terkait teknis pelaksanaan program dariDinasPerikanan Kabupaten Pamekasan bahwasannya hanya ketua atau perwakilan kelompok yang mengikuti kegiatan sosialisasi atau pelatihan. Dari teknis pelaksanaan tersebut dapat dilihat sikap-sikap yang dimiliki oleh petani garam khususnya 
yang mengikuti kegiatan sosialisasi atau pelatihan. Ketua atau perwakilan kelompok memiliki tanggung jawab untuk menyampaikan informasi kepada petani lain yang tidak mengikuti kegiatan sosialisasi atau pelatihan. Menurut pengakuan informan (AS) bahwa semua informasi bahkan saran dari dinas terkait yang diterima melalui pelatihan atau sosialisasi selalu disampaikan kepada anggota kelompoknya. Aktivitas tersebut juga dilakukan oleh informan yang memiliki posisi sebagai ketua kelompok petani garam (SG).

Namun, karena ada beberapa permasalahan yang bersifat pribadi seperti: 1) pembagian lahan tambak garam antar saudara, 2) tiap lahan memiliki tingkat produktifitas yang berbeda, dan 3) pola pikir sebagian petani garam yang merasa "cukup" bahkan merasa "bisa" atas pengetahuan dan keterampilan yang dimiliki dalam membuat garam - menyebabkan program yang dicanangkan pemerintah sebagian menjadi tidak terealisasi. Diantara program yang sebagian belum dapat direalisasikan oleh sebagian petani garam adalah integrasi lahan. Permasalahan tersebut hingga sekarang masih belum terselesaikan.

Namun, disisi lain - dengan munculnya berbagai permasalahan tersebut, kegiatan sosialisasi dan pelatihan dengan mengikutsertakan ketua atau perwakilan kelompok telah membantu terbentuknya self concept petani garam sehingga menumbuhkan sikap untuk mengembangkan kompetensi petani garam lain melalui "sambung" informasi dan yang paling esensial adalah sikap dalam menolong orang lain melalui informasi yang diberikan sehingga secara tidak langsung membantu meningkatkan kompetensi dan kesejahteraan petani garam lain. Pendampingan yang dilakukan secara berkesinambungan juga membantu petani garam untuk lebih kooperatif terhadap pihak-pihak luar yang berkeinginan menjalin kerjasama.

\section{Karakteristik pribadi/sifat (traits)}

Karakteristik

pribadi/sifat merupakan salah satu aspek kompetensi yang tidak nampak sehingga sulit untuk diidentifikasi. Namun dari wawancara mendalam ditemukan beberapa fakta terkait karakteristik pribadi/sifat (traits) yang dimiliki petani garam seperti menghargai perbedaan dan pandangan yang bertentangan atas suatu isu serta keyakinan seseorang pada kemampuan diri untuk menyelesaikan tugas dan kemampuan menyesuaikan diri (Spencer \& Spencer, 1993: 10). Sebagian petani menganggap bahwa membuat garam dengan teknologi geo isolator/geo membran menyebabkan rasa garam menjadi pahit sehingga memutuskan untuk tetap menggunakan cara tradisional. Sedangkan sebagian petani juga membenarkan adanya isu tersebut namun memutuskan menggunakan teknologi geo isolator/geo membran. berdasarkan pengakuan informan (AS), alasan yang mendasari adalah hasil yang diperoleh lebih banyak dan lebih bersih. Meskipun area lahan berdampingan tetapi menggunakan teknologi yang berbeda, petani garam di Kabupaten Pamekasan hidup berdampingan secara damai.

Terkait keyakinan terhadap kemampuan diri dalam menyelesaikan tugas, pengalaman mengelola lahan 
tambak garam secara mandiri atau tidak, berpengaruh terhadap keyakinan diri akan kemampuan yang dimiliki. Hal tersebut dibuktikan dari pengakuan beberapa informan (SB, AS, dan SG) yang mengatakan bahwa semakin lama seseorang berkecimpung dalam usaha produksi garam maka memiliki keyakinan atas kemampuan diri dalam memproduksi garam. Artikulatif dengan pernyataan tersebut, petani garam yang baru saja mengikuti orang tuanya menjadi petani garam (AB) merasa belum memiliki kemampuan dalam memproduksi garam secara mandiriartinya tanpa pendampingan dari orang tua. Hal ini berarti bahwa model social learning membantu dalam pembentukan karakteristik pribadi/sifat.

Karakteristik

pribadi/sifat merupakan salah satu aspek kompetensi selain tidak nampak sehingga sulit untuk diidentifikasi, juga merupakan salah aspek yang sulit untuk berubah. Namun bukan sesuatu yang yang tidak dapat berubah (Zwell dalam Wibowo, 2007: 102). Upaya diri untuk sering melakukan pengamatan baik secara mandiri atau terprogram seperti melakukan diskusi dengan petani garam lain yang lebih berpengalaman, sering melakukan pengamatan cara memproduksi garam, sering bekerja dalam tim serta sering mengikuti kegiatan sosialisasi dan pelatihan merupakan beberapa kegiatan yang bisa meningkatkan keyakinan diri.

\section{Motif (motives)}

Motif(motives)yang dimilikiseseorang dalam menekuni suatu kegiatan berbeda dengan orang lainnya. Begitupun juga motif petani garam di kabupaten Pamekasan ketika memutuskan untuk menjadi seorang petani garam. Motif salah satu petani garam (AB) adalah tertarik dengan harga garam yang tinggi saat ini. Berbeda dengan petani garam lain (MS) - yang menjadi petani garam dikarenakan tidak ada pekerjaan lain lagi yang bisa dikerjakan untuk seorang anak yang waktu itu berusia 12 tahun. Ada juga dengan motif meneruskan usaha keluarga (SG, AS, SB dan HM).

Dari berbagai motif yang mendasari tersebut dan mengacu pada teori kebutuhan Maslow (1994: 81), secara umum mengarah untuk pemenuhan kebutuhan fisiologis (physiological needs) yakni pemenuhan kebutuhan untuk mempertahankan hidup secara fisik seperti kebutuhan makan, minum, tempat berteduh atau yang disebut juga kebutuhan akan sandang, pangan dan papan. Kebutuhan yang memiliki tingkatan lebih tinggi seperti kebutuhan akan penghargaan (esteem needs)kebutuhan akan status, ketenaran, kompetensi, prestasi dll belum dimiliki oleh sebagian petani garam di kabupaten Pamekasan sehingga diprediksi belum siap untuk masuk ke dalam kebutuhan aktualisasi diri (selfactualization needs). Hal ini seharusnya menjadi kajian serius agar para petani tidak hanya memiliki motif pada pemenuhan kebutuhan fisiologis (physiological needs) saja, melainkan lebih dari itu, yaitu memiliki motif terhadap kebutuhan akan penghargaan (esteem needs) atau bahkan pada level yang tertinggi yaitu kebutuhan aktualisasi diri (self actualization needs). 


\section{KESIMPULAN DAN SARAN}

Peningkatan kompetensi petani garam melalui model social learning dilakukan dengan menyajikan contoh perilaku (modeling) dari aspek: 1) pengetahuan (knowledge) yaitu informasi yang dimiliki petani garam untuk membuat atau memproduksi garam, 2) keterampilan (skill) yaitu kemampuan untuk mengaplikasikan pengetahuan dalam membuat garam, 3) konsep diri (self concept) yaitu sikap dan nilai petani garam dalam mengembangkan diri dan orang lain, 4) karakteristik pribadi/sifat (traits) yaitu watak untuk mengontrol setiap perilaku misalnya ketika menghadapi cobaan dan tantangan, dan 5) motif (motives) yaitu kekuatan pendorong untuk mencapai tujuan. Implementasi terhadap kelima aspek tersebut seharusnya dilakukan secara seimbang tidak terfokus pada salah satu aspek saja.

Peran model social learning untuk peningkatan petani garam di kabupaten Pamekasan diantaranya, 1) petani garam memiliki pengetahuan sehingga memiliki beberapa alternatif cara untuk terampil dalam membuat garam hingga produksinya melimpah dan berkualitas, 2) menumbuhkan sikap untuk mengembangkan kompetensi petani garam lain melalui penyampaian informasi, 3) menumbuhkan sikap menolong orang lain, dan 4) menumbuhkan sikap kooperatif terhadap pihak-pihak luar yang berkeinginan menjalin kerjasama.

Hasil penelitian ini dapat dijadikan model alternatif untuk menyelesaikan permasalahan dalam upaya peningkatan kompetensi sumber daya manusia manusia di Kabupaten Pamekasan.

\section{DAFTAR PUSTAKA}

Bandura, Albert. 1986. Social Foundation of Thought and Action: A Social Cognitive Theory. Englewood Cliffs, NJ: Prentice-Hall.

Denzin, Norman K., and Yvonna S. Lincoln. 1994. "Introduction: Entering the Field of Qualitative Research." Norman K. Denzin and Yvonna S. Lincoln (eds.), Handbook of Qualitative Research, pp. 117. Thousand Oaks, California: Sage.

Dinas Perikanan dan Kelautan Kabupaten Pamekasan. 2015. Profil Garam Rakyat. Pamekasan: Dinas Perikanan dan Kelautan Kabupaten Pamekasan.

Huberman, A. Michael and Matthew B. Miles. 1994. "Data Management and Analysis Methods." Norman K. Denzin and Yvonna S. Lincoln (eds.), Handbook of Qualitative Research, pp. 428-444. Thousand Oaks, California: Sage Publications Inc.

Maslow, Abraham. H. 1994. Motivasi dan Kepribadian: Teori Motivasi dengan Pendekatan Hierarki Kebutuhan Manusia, Nurul Imam (Terj.). Jakarta: Pustaka Binaman Pressindo.

Moleong, Lexy J. 2000. Metodologi Penelitian Kualitatif. Bandung: PT Remaja Rosdakarya.

Neuman, W. Lawrence. 2000. Social Research Methods. Boston: Allyn and Bacon.

Ricklefs, M. C. 2007. Sejarah Indonesia Modern, Satrio Wahono dkk (Terj.). Jakarta: Serambi Ilmu Semesta.

Spencer, Lyle \& Signe M. Spencer. 1993. Competence at Work, Models For Superior Performance. Canada: John Wiley \& Sons, Inc.

Sulistyorini, Dwi. 2006. "Upacara Nadar dalam Pembuatan Garam di Sumenep (Fungsi, Simbol dan Pemaknaannya." Jurnal Bahasa dan Seni, Vol. 34, No. 2, Agustus 2006. 
Syah, Muhibbin. 2013. Psikologi Pendidikan dengan Pendekatan Baru. Bandung: PT Remaja Rosdakarya.

Wahyudi, Muhtar. 2015. “Jurus Ombak dan Angin: Komunikasi Politik Si Pencari Ikan." Dalam Surokim (Ed.), Madura: Masyarakat, Budaya, Media dan Politik, hal. 2-16. Yogyakarta: Elmatera.

Wibowo. 2007. Manajemen Kinerja. Jakarta: PT. Raja Grafindo Persada.

Yusuf, Muri. 2017. Metode Penelitian Kuantitatif, Kualitatif dan Gabungan. Jakarta: Kencana. 